\title{
Development of an educational tool on tinnitus in a website format
}

\author{
Raissa Pereira Carvalho ${ }^{1}$ \\ https://orcid.org/0000-0002-3053-7111 \\ Jerusa Roberta Massola de Oliveira ${ }^{2}$ \\ https://orcid.org/0000-0001-8771-3588 \\ Maria Fernanda Capoani Garcia Mondelli ${ }^{1}$ \\ https://orcid.org/0000-0001-7572-209X \\ Izabella Lima de Matos ${ }^{1}$ \\ https://orcid.org/0000-0002-4474-1156
}

Universidade de São Paulo - Faculdade de Odontologia de Bauru, Bauru, São Paulo, Brasil.

2 Hospital de Reabilitação de Anomalias Craniofaciais, Bauru, São Paulo, Brasil.

Conflict of interests: Nonexistent

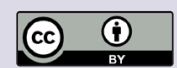

Received on: April 24, 2020

Accepted on: September 8, 2020

Corresponding address:

Raissa Pereira Carvalho

Rua Silvio Marchione 3-20,

Vila Universitária

CEP: 17012-900 - Bauru, São Paulo,

Brasil

E-mail: raissa.pc@outlook.com

\section{ABSTRACT}

Objective: to develop an educational tool in a Virtual Learning Environment (VLE), in a website format, to supply information on tinnitus, additional content on hearing and to provide access links to other websites related to speech therapy and audiology, so as to promote public health.

Methods: an experimental, descriptive study, involving, in its construction, 6 stages elaborated as follows: planning, adaptation, collection of testimonies, inclusion of content, review and dissemination.

Results: the site was titled "Do you have tinnitus?" It was subdivided into others: "Home", "Tinnitus?" "Types of tinnitus," "Main causes," "What to do?" "Main forms of treatment," "Tips to relieve tinnitus," "Prevention," "News," "Testimonials," "About your hearing," "What is hearing loss?" "What are speech therapy and audiology?" "Other sites," "Contact" and "About." Illustrations and videos were inserted, and the information contained in any material was classified with easy readability.

Conclusion: it was possible to develop a website entitled "Do you have tinnitus?" available at the electronic address: https://vocetemzumbido.wixsite.com/home, providing general information about tinnitus, in addition to additional information on hearing.

Keywords: Tinnitus; Hearing; Education, Distance 


\section{INTRODUCTION}

Tinnitus is considered an otoneurological symptom defined as the perception of a sound without an external generating source, occurring in a transient or chronic way, affecting one, two ears or the head ${ }^{1,2}$.

In Brazil, there are no official epidemiological studies that reveal the prevalence of tinnitus, but it is estimated that millions of Brazilians are affected at some stage in their lives, being a symptom with high occurrence ${ }^{3,4}$.

It is one of the most unpleasant symptoms that affects the human being, with possible interferences in the individual's quality of life, which can aggravate or even cause anxiety or depression ${ }^{5,6}$. Studies state that 1 to $3 \%$ of the population affected by tinnitus has more serious consequences in daily life ${ }^{7,8}$.

Objective tinnitus is audible to other people as a sound whose source seems to be in the external auditory canal. Its causes are varied and may be due to cardiac, circulatory noise, due to abnormal contractions of the muscles of the middle ear, linked to the presence of neurinoma, among others; subjective tinnitus is concentrated in most cases, and is audible only to the individual. It results from abnormal nervous signals in the auditory pathways, and once in the auditory cortex, it causes sound perception ${ }^{9}$.

Its psychoacoustic characteristics include: frequency / pitch (low, medium or high) and intensity / loudness (strong or weak) being able to consider the duration (constant, intermittent, fluctuating), the type (whistle, cricket, pressure cooker siren, etc.).) and whether the sound is single or multiple ${ }^{10}$.

Its etiology is wide, and may have an otological, cardiovascular, neurological, infectious, pharmacological, psychogenic, metabolic, dental and psychoactive origi ${ }^{11,12}$. There are cases in which pathologies are associated, which often occurs in the elderly. This sum can negatively affect the discomfort caused ${ }^{12,13}$.

The degree of discomfort varies, according to the individual's psychological aspects (irritability, personality traits, difficulty in dealing with the problem and anxiety), and / or when there are comorbidities. The characteristics of the symptom (intensity, frequency and location) are less related to this aspect ${ }^{5,6}$.

Different studies correlate hearing loss and tinnitus, associating it with almost all abnormalities of the ear, with more frequent cochlear alterations. The isolated presence of the symptom is due to other pathologies, and there are cases in which the underlying disease is not discovered ${ }^{1,14}$.
For diagnosis, it is necessary to survey the clinical history with information about the symptom, description, location, level of discomfort and other characteristics. The use of questionnaires is also quite effective since it helps to confirm the degree of severity and how much it affects the quality of life. Some used are: Tinnitus Handicap Inventory (THI), Tinnitus History Questionnaire (THQ) and Tinnitus Questionnaire (TQ). Another tool is the visual analog scale (VAS) that measures the degree of pain, discomfort and / or suffering caused by a certain symptom. There is also acuphenometry, an exam aimed at characterizing the pitch and loudness of tinnitus using the pure tone stimulus ${ }^{15,16}$.

Different methods are used to relieve the symptom, such as tinnitus sound therapy approaches, among which we can mention: Tinnitus Retraining Therapy (TRT), Tinnitus Activities Treatment (TAT) and Tinnitus Masking (TM). These interventions are based on directive, informative and sound counseling in conjunction with the use of sound generating systems (GS) that vary according to the intervention used, the type of tinnitus and other patient particularities ${ }^{16,17}$.

The use of an individual hearing aid (IHA) is also described in the literature as a way of controlling the symptom in patients with hearing loss since exposure to the sound world can mask or cause habituation to it, that is, the patients auditory stimuli amplified by the device decrease the perception of tinnitus. They can present a sound generator which produces broadband noises, music for relaxation or stimulus with spectral modification, and with the same purpose of amplification devices, enrich the sound world and collaborate for habituation to occur ${ }^{18}$.

Tinnitus can interfere very negatively in the quality of life, making people more stressed and irritated. An alternative treatment is individual psychotherapy or participation in groups in order to minimize the stress caused and consequently reduce its impact.19,20 As already explained, counseling is also a tool used mainly by speech therapists, consisting of strategies to facilitate tinnitus habituation, increase understanding about the symptom, prognosis and mitigate its consequences. This approach is usually associated with tinnitus sound therapy ${ }^{18}$. There is also the possibility of consultations with nutritionists and physical educators to balance food and exercise in order to reduce stress and lead to possible improvement ${ }^{21}$.

In general, to prevent tinnitus, periodic audiological assessments are recommended, care with food (for 
example, coffee and alcohol when ingested in excess can worsen and / or elicit tinnitus), regular exercise, adequate sleep quality, avoid stress and environments with sound at high sound pressure levels ${ }^{22,23}$. For people working in noisy environments, the use of hearing protectors is essential since prolonged exposure to noise can cause hearing loss and stress, factors that increase the likelihood of being affected ${ }^{24}$.

Professionals and students use the digital medium to inform, educate and carry out procedures at a distance, with this, terms such as Telecare, e-Health and Telehealth have emerged, all of which have the same principle. Basically, we can group telehealth into: Interactive tele-education and collaborative learning network, Tele-assistance / epidemiological surveillance and regulation and Multicentric research / collaboration of centers of excellence and the "Telescience" network ${ }^{25}$.

The objective of the present work was to develop an educational tool in a Virtual Learning Environment (VLE), in a website format, which provides information on tinnitus, such as definition, causes and treatment of this symptom, in addition to additional information on hearing, and provides access links to other websites related to speech therapy, aimed at promoting the health of the target public.

\section{METHODS}

The present study is an experimental, descriptive study approved by the Research Ethics Committee of the Bauru School of Dentistry - FOB-USP), Bauru, SP, Brazil, under number 2,223,386, for the construction of a virtual environment (Website), based on the theoretical model proposed by Filatro and Piconez26 for the purpose of elaborating digital educational material based on the themes "tinnitus" and "hearing", with the aim of synthesizing theoretical-scientific-practical knowledge containing 6 steps for the following phases: conceptualization, development and implementation. It is noteworthy that, for the making of the website, there was no hiring or co-participation of computer or design professionals, only occasional consultations regarding the VLE's aesthetics. Therefore, the entire interface was developed by the authors.

\section{First stage: Planning, selection and analysis of the website's textual content}

The development of the Website content was based on searches in databases indexed as Lilacs; Pubmed;
Scielo; Google Scholar. For the standardization of the language of scientific materials, descriptors in Portuguese and their English counterparts in consultation with Descriptors in Health Sciences (DeCS) were used as a search strategy. The following descriptors were used alone or in combination: tinnitus, intervention, health promotion, distance education; in English: tinnitus, intervention, health promotion, distance education.

The contents selected to compose the Website should address one or more of the following information: tinnitus (definition, classification, cause, treatment, prevention) and hearing (physiology of hearing, hearing loss and its prevention).

\section{Second stage: Adequacy of the website's textual content and selection of digital media}

For word processing, the Microsoft Word 2010 program was used, aiming at building a dynamic, didactic and practical digital tool that would meet the needs of the target audience.

The content used was adapted with respect to language to facilitate the understanding of the information by the target audience and resources such as images and videos with the same objective were added. At this stage, the language level of the content was checked using the Flesch Reading Index, adapted to Brazilian Portuguese. This tool assesses the compatibility between the text displayed and the language of the target audience ${ }^{27}$.

For the selection of images, the database provided by the provider on which the site is hosted (WIX) was used, which are available under license for free. Searches were also carried out in the databases (Google and Yahoo) in order to select relevant links to be made available. In the case of videos (except the testimonials that are produced by the authors), they are hosted on the YouTube platform so that accessing the content through the website is equivalent to accessing the author's channel since VLE only creates a shortcut access to the original platform.

\section{Third stage: Collection of testimonials about tinnitus}

In order to bring the reader closer to the VLE, testimonies from individuals who had tinnitus were previously collected who reported their perception of this symptom. Such content was inserted on the Website. 


\section{Fourth step: Inclusion of textual and non-textual content (graphic design) on the Website}

In this stage, the base platform for creating the site was selected so that it would allow intuitive navigation and varied resources made available for free. After the selection, the contents were inserted according to the pre-established organization.

In this phase, there was also the choice of font style such as type and number, colors and positioning of textual and non-textual material aiming to make them attractive and with greater clarity for the target audience.

\section{Fifth step: Review of textual and non-textual content (graphic design) on the website}

A review of the website's textual content was carried out, looking for possible spelling errors, poorly positioned or illegible information and duplicate content. The design of the tabs (colors and positioning), functionality of the media, navigation mode and access to the links were also checked.

\section{Sixth stage: Implementation and dissemination of the Website}

The Website was implemented online by enabling this tool in the global computer network system, that is, the Internet, allowing the search of the virtual environment on the main search and linked websites. The disclosure was carried out on the main social networks such as Facebook, Instagram and WhatsApp and via e-mail, through a standard text prepared by the author who invites and informs what can be found on the website.

\section{RESULTS}

The website entitled "Do you have tinnitus?" is presented in 11 main topics and five subtopics, totaling 16 available pages. It has tabs to solve possible doubts or personal considerations, allowing the reader to contact the author. In addition, it has identification of the team that created the VLE, which allows the authors to get closer to the target audience. Below, in Figure 1 , the main page of the website is presented so that you can have a better representation of some visual elements that will be mentioned below.

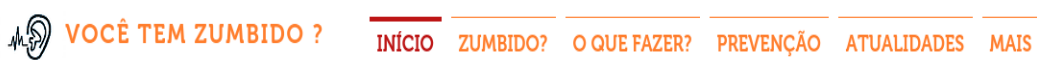

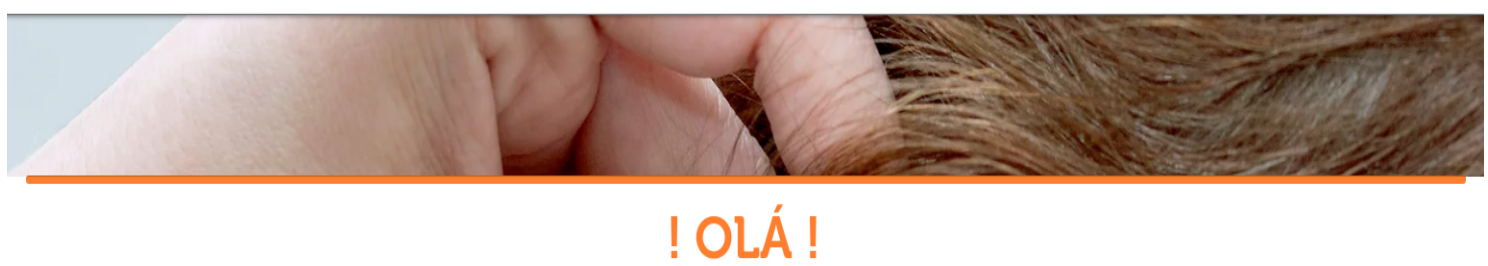

\begin{abstract}
Se surgir alguma dúvida, comentário, critica e/ou sugestão envie para nós por meio da aba contato. Também existe uma aba com links de websites que abordam outras áreas da fonoaudiologia que você pode se interessar, confira clicando aqui !

Esperamos que essas informações o ajudem, desejamos uma ótima navegação.
\end{abstract}

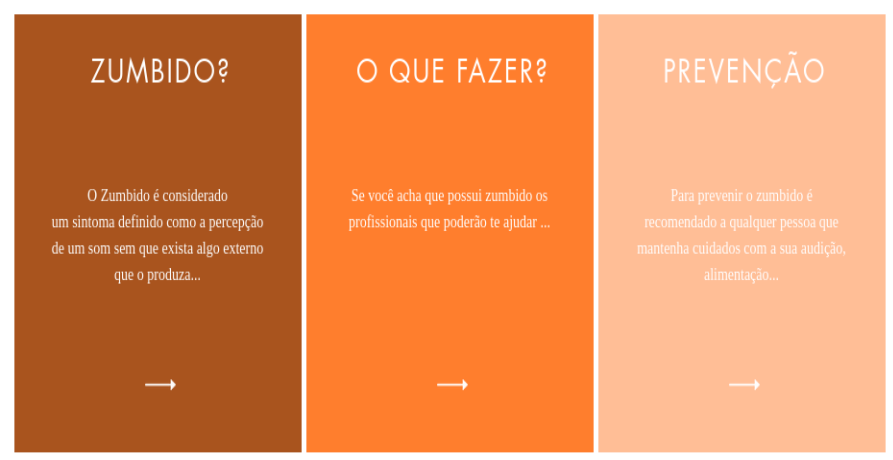

Figure 1. Interface of the main website page 
The results of the website elaboration are presented below according to the following steps:

\section{First step: Planning, selection and analysis of website content}

After selecting the contents that would compose the virtual environment, the construction of the information layout occurred, creating the sub-themes presented in Figure 2.

\section{Second step: Adequacy of the website's textual content and selection of digital media}

In the adequacy of the textual content of the Website, the language level of the content assessed by the Flesch Reading Index resulted in approximately $91.7 \%$ of the information contained in the material being classified with easy readability, according to the level of understanding of the desired target audience.

\section{1 - DISPOSAL OF INFORMATION IN THE VIRTUAL ENVIRONMENT (TABS)}

1. Home

2. Tinnitus?

a. Types of tinnitus

b. Main causes

3. What to do? (Which professionals to look for?)

a. Main forms of treatment

b. Tips to relieve tinnitus

\begin{tabular}{|ll|}
\hline 4. & Prevention \\
\hline 5. & News \\
\hline 6. & Testimonials \\
\hline 7. & About your hearing (how do we hear?) \\
a. What is hearing loss? \\
\hline 8. & What is speech therapy? \\
\hline 9. & Other sites \\
\hline 10. & Contact \\
\hline 11. & About \\
\hline
\end{tabular}

Figure 2. Arrangement of information in the virtual environment

The digital media (images and videos) selected in order to contextualize the reader and motivate him to browse were made available in the VLE and it is possible to view them in the access link.

\section{Third step: Collection of testimonials about tinnitus}

Three testimonies were collected, one participant beginning treatment for the tinnitus symptom with an individual hearing aid and two already being hearing aid users together with the sound generator to whom they reported their experiences and their different points of view. The participants authorized the disclosure of the footage by signing the document called "The Authorization Term for Use of Sounds and Images." Finally, edits and caption insertion were carried out.

\section{Fourth step: Inclusion of textual and non-textual content (graphic design) on the Website}

The Wix platform was selected as the basis for creating the virtual environment. It provides the insertion of content on the Website through tabs, and the selected and collected materials and media were included according to the division by sub-themes elaborated in the analysis stage, content planning and elaboration. Inside the Wix Tool, the free creation mode was used. The pages were created using the available configurations, this being a crucial step for the elaboration of the VLE design.

\section{Fifth step: Review of textual and non-textual content (graphic design) on the website}

The following modifications were necessary according to Figure 3 . 


\begin{tabular}{|c|c|}
\hline Inadequacy & Modification performed \\
\hline \multicolumn{2}{|l|}{ Tab: Main causes } \\
\hline $\begin{array}{l}\text { a. Words: conductive and sensorineural directing to another } \\
\text { site. }\end{array}$ & $\begin{array}{l}\text { a. Words direct to the "What is hearing loss?" Tab. } \\
\text { b. Phrase leads to the "Prevention" tab. }\end{array}$ \\
\hline b. Phrase: "hearing protection" directing to another website. & c. Acronym TMJ directs to the video "What is TMJ? And \\
\hline $\begin{array}{l}\text { c. Acronym TMJ directing to website with invalid } \\
\text { information. }\end{array}$ & $\begin{array}{l}\text { what are TMJ disorders?". Available at }<\text { https://www. } \\
\text { youtube.com/watch?v=xO0g8F0xE6U > }\end{array}$ \\
\hline $\begin{array}{l}\text { d. Sentence: These changes can cause tinnitus, which can } \\
\text { worsen in sedentary conditions. }\end{array}$ & $\begin{array}{l}\text { d. Reformulated: These changes can cause tinnitus, which } \\
\text { worsens in sedentary conditions. }\end{array}$ \\
\hline \multicolumn{2}{|l|}{ Tab: Main forms of treatment } \\
\hline $\begin{array}{l}\text { a. Phrase: Sound generators are devices that are produce } \\
{[\ldots] .}\end{array}$ & a. Sentence construction (are) removed. \\
\hline \multicolumn{2}{|l|}{ Tab: Tips to relieve tinnitus } \\
\hline $\begin{array}{l}\text { a. Sentence: Exercising contributes in general to the general } \\
\text { health of our body [...]. }\end{array}$ & $\begin{array}{l}\text { a. Reformulated to: Exercising contributes in general to the } \\
\text { health of our body [...]. }\end{array}$ \\
\hline \multicolumn{2}{|l|}{ Tab: About your hearing } \\
\hline $\begin{array}{l}\text { a. The text started with: In this video you can see what } \\
\text { happens when we hear. } \\
\text { b. Back to Home button did not direct. }\end{array}$ & $\begin{array}{l}\text { a. Withdrawn. } \\
\text { b. Button started to direct to the "Home" tab. }\end{array}$ \\
\hline
\end{tabular}

Figure 3. Modifications after reviewing the textual content

\section{Sixth step: Implementation and dissemination of the Website}

The implementation of the Website was possible and it was published on social networks (Facebook, Instagram and WhatsApp) and via email, using the standard text:

"Good morning / afternoon / night, do you know anything about tinnitus?

Enter the site and discover information about what it is, treatment and prevention, in addition, you can stay on top of news and access other interesting sites for your health and your family. And just click on this link: https://vocetemzumbido.wixsite.com/ home."

\section{DISCUSSION}

One of the most used means of transmitting information is the Internet since it allows quick and easy access to various virtual environments, in addition to encouraging the entry of new information. Other advantages include: overcoming the geographical and time barrier.

Between the 70 s and $80 \mathrm{~s}$, the Internet started to be used for academic purposes, where teachers and students exchanged information. In the 90s, it became popular, together with the creation of the World Wide Web (WWW), allowing the creation and development of Websites, which are more interactive and dynamic, which significantly contributed to the accelerated growth of this medium of information transmission ${ }^{28,29}$.

Since its popularization, the number of Internet users has grown concomitantly with the facilitation of use, device innovations, forms of navigation and the creation of more efficient and accurate search engines, as well as the emergence of social networks, factors that have contributed to retain access and increase the number of users at a great speed ${ }^{28}$.

The information revealed above strengthens the use of the Internet as an efficient means of transmission, being the best way to make available to a large part of the population what is desired, particularly in the present study, information about tinnitus.

Analyzing other ways of spreading information, such as printed ones, greater efforts would be needed to reach a large number of people, in addition, the material in printed form deteriorates over time. In other media, such as radio and television, there are barriers, since the transmission has a defined and limited time, in addition, both have a high cost for its realization and implementation. On the other hand, making information available on the Internet is fast, free and timeless.

The basic platforms for creation offer several tools that contribute to attract the reader, promoting a more dynamic virtual environment with navigation facilities. Another great advantage is that access can be performed at any time, without limit of geographical barriers, requiring only one device with a connection. The content is protected maintaining its initial integrity 
and does not deteriorate over time, and can be modified according to innovations and needs.

It is a fact that health information is among the most searched topics by Internet users, and currently there is a great insertion and availability of content related to this theme and its various aspects. One of the most frequent issues is that of health promotion, disease prevention, treatment and work carried out by professionals. The term used since the $90 \mathrm{~s}$, with regard to the transmission of this information is called Telemedicine, defined as the transmission of knowledge and health care at a distance. Later, other terms suggested such as Telecare, e-Health, Telehealth and Telehealth, but the principle is the same. Telehealth has three fronts of work. In the present study Interactive Teleducation and Collaborative Learning Network were used, which are terms that refer to the use of technologies to expand knowledge, that is, use it for educational purposes such as distance learning or support for faceto-face education with additional activities. Another way of conceptualizing Telehealth is called the Virtual Learning Environment (VLE), defined as the availability of resources and information on the Internet, integrating accessible language and multiple media in an organized way to foster interactions between people and content, aiming to achieve public learning- target and propose free knowledge, respecting the time of each individual to absorb information ${ }^{25,20}$.

For the effectiveness of a VLE, it is necessary to make information available using various tools and resources in order to provide greater interest in the learning process, facilitate access and provide the integration of available content and their daily situations ${ }^{25}$. Different studies have positively evaluated the use of these environments as a way of disseminating information through the Internet, integrating content and resources, in addition to showing that the web is a good means of disseminating knowledge ${ }^{31-33}$.

Thus, the present study created a website aimed at those who wish to know more about the tinnitus symptom. The theme was chosen considering that this category is not reliably disseminated on the Internet. Its importance is evidenced by avoiding possible aggravations due to misinformation and by encouraging people with tinnitus to understand their problem and seek treatment, or by adding knowledge and promoting health prevention. In general, the dissemination of the information provided is expected to occur.

In the VLE, information on tinnitus, hearing and speech therapy was inserted, in addition to providing access links to pages in the scope of health already produced by university programs.

Following the guiding principles of tele-education and VLE, the contents of the website developed were designed in order to provide the best understanding and absorption of the information offered. For this purpose, tools were used to increase the reader's interest and bring the disseminated content closer to everyday life.

It is worth mentioning that the tool known as the Flesch index of readability was essential to verify the adequacy of the language of the contents to the target audience, since, in scientific productions, reading is often difficult for people not adapted to speech therapy technical terms ${ }^{27}$.

It was observed that the creation of this website made it possible to present links that provided greater and more specific clarifications to users. In addition, in order to provide greater interaction, a visit counter and a contact tab were made available, where visitors can send their questions to the developers of this VLE. Until now, there have been some questions from Internet users that have been remedied since the environment was developed recently, and until then, dozens of accesses have been counted.

It is known that the information is liable to change and new research with new content is made available frequently, therefore, the contents of the site will be reviewed every six months by the authors with a higher frequency being adopted for the news tab, changing as new news is released.

Researchers who developed different productions in the creation of virtual environments, in order to inform the population on the most diverse subjects, emphasize that there should be concern not only in relation to content and language, but also in design, attractions and the opinion of third parties ${ }^{31,32}$.

Regarding the website developed in the present work, it is important to emphasize that improvements must be promoted in order to study the interaction of users with the VLE, as well as perform validation processes, content and design, promoting improvements in order to improve the experience, add new functions and information to the site. Finally, there is a need for greater availability of health information using distance education technology to enable the dissemination of information in places where the professional is not present. 


\section{CONCLUSION}

It was possible to develop an educational tool in an VLE, in a website format, entitled "What do you know about tinnitus?". It is available at the electronic address: https://vocetemzumbido.wixsite.com/home, providing general information about tinnitus, plus additional information about hearing.

\section{REFERENCES}

1. Levine RA, Oron Y. Zumbido. In: Aminoff JM, Boller F, Swaab DF (eds). O sistema auditivo humano. Amsterdã: Elsevier; 2015. p.409-31.

2. Martinez C, Wallenhorst C, Mcferran D, Hall DA. Incidence rates of clinically significant tinnitus: 10-year trend from a cohort study in England. Ear and hearing. 2015;36(3):e69.

3. Oiticica J, Bittar RSM. Tinnitus prevalence in the city of São Paulo. Braz J Otorhinolaryngol. 2015;81(2):167-76.

4. Chamouton CS, Nakamura HY. Tinnitus and primary health care: a literature review. Distúrb. Comun. 2017;29(4):720-6.

5. Castro TPPG, Handro ML, Tenório YCA, Castro MTPG. Tontura e zumbido em pacientes com transtorno de ansiedade e/ou depressivo maior. Rev. Equilíbrio Corporal Saúde. 2017;9/10(1):39-42.

6. Rocha GSR, Vargas MM, Gomes MZ. Quality of life in individuals with tinnitus with and without hearing loss. Rev. CEFAC. 2017;19(6):764-72.

7. Kim HJ, Lee HJ, An SY, Sim S, Parque B, Kim SW et al. Analysis of the prevalence and associated risk factors of tinnitus in adults. PLoS ONE. 2015;10(5):e0127578.

8. Handscomb LE, Hall DA, Shorter GW, Hoare DJ. Positive and negative thinking in tinnitus: fator structure of the tinnitus cognitions questionnaire. Ear Hear. 2017;38(1):126-32.

9. Shea PF, McKinnon BJ. Zumbido idiopático subjetivo na população geriátrica. In: Sataloff RT, Johns III MM, Kost KM (orgs). Otorrinolaringologia em geriatria. 1 ed. Rio de Janeiro: Revinter; 2017. p. 90-3.

10. Suzuki FAB, Suzuki FA, Onishi ET, Penido NO. Classificação psicoacústica do zumbido persistente. Braz. j. otorhinolaryngol. 2018;84(5):583-90.

11. Lucena DG, Lima LHMA. Análise da presença do zumbido em pacientes com disfunção temporomandibular: Autorrelato [trabalho de conclusão de curso]. Campina Grande (PB):
Universidade Estadual da Paraíba, Curso de Odontologia; 2016.

12. Onishi TE, Coelho CCB, Oititica J, Figueiredo RR, Guimarães RCC, Sanchez TG et al. Zumbido e intolerância sonora: evidências e experiências de um grupo brasileiro. Braz. j. otorrinolaringol. 2018;84(2):135-49.

13. Ferreira GC, Costa DL, Muller MD, Costa MJ. Tinnitus complaint and health changes. Distúrb. Comum. 2017;29(4):711-9.

14. Zarenoe R, Ledin TA. Cohort study os patients with tinnitus and sensorioneural hearing loss in a Swedish population. Auris Nasus Larynx. 2013;40(1):41-5.

15. Wazen JJ, Daugherty J, Pinsky K, Newman CW, Sandridge S, Battista $R$ et al. Evaluation of a costumizade acoustical stimulus system in the treatment of chronic tinnitus. Otology e Neurology. 2013;32(4):710-6.

16. Cabreira AF, Mondelli MFCG. Gerador de som: análise da eficácia dos ruídos mascaradores no alívio do zumbido [Dissertação]. Bauru (SP): Faculdade de Odontologia de Bauru, Universidade de São Paulo; 2016.

17. Vernon JA, Meikle MB. Tinnitus masking. In: Tyler RS (ed). Tinnitus handbook. Cengage Learning; 2000. p. 313-56.

18. Rocha AV, Mondelli MFCG. Gerador de som associado ao aconselhamento no tratamento do zumbido: avaliação da eficácia. Braz. j. otorhinolaryngol. 2017;83(3):249-55.

19. Stephanie FL, Patricia CM. Zumbido crônico em idosos: uma proposta de intervenção. Estud. interdiscipl. envelhec. 2016;21(3):295-308.

20. Vinagre LM, Guariento ME. Tratamento clínico de zumbido primário em adultos e idosos: revisão sistemática. Rev. Soc. Bras. Clín. Méd. 2019;16(4):249-54.

21. Arizola HGA, Teixeira AR. Impacto do zumbido em idosos praticantes e não praticantes de exercício físico. ConScientiae Saúde. 2015;14(1):80-8.

22. Santana BAS, Alvarenga KF, Cruz PC, Quadros IA, Jacob-Corteletti CB. Prevention in a school environment of hearing loss due to leisure noise. Audiol., Commun. Res. 2016;21:e1641.

23. Viana LS, Teixeira KMD. Consequências da perda auditiva e, ou, do zumbido na qualidade de vida, no trabalho e nas relações sociais [Tese]. Viçosa (MG): Universidade Federal de Viçosa, Programa de Pós-Graduação em Economia Doméstica; 2016. 
24. Oliveira RC, Santos JN, Rabelo ATV, Magalhães MC. The impact of noise exposure on workers in Mobile Support Units. CoDAS. 2015;27(3):215-22.

25. Silva E. A telessaúde e seus impactos na formação continuada dos profissionais de saúde em rede. Rev. Em Rede. 2017;4(1):116-29.

26. Filatro A, Piconez SCB. Design instrucional contextualizado: planejamento, elaboração e avaliação de materiais didáticos para educação a distância. 2004; Disponível em: http://www.abed. org.br/congresso2004/por/htm/049-TC-B2.htm.

27. Martins TBF, Ghiraldelo CM, Nunes MGV, Oliveira Junior ON. Readability formulas applied to textbooks in Brazilian portuguese. Instituto de Ciências Matemáticas de São Carlos-USP. 1966; PDF Version disponível em: http://www.nilc.icmc. usp.br/nilc/download/Reltec28.pdf.

28. Rocha GC, Souza Filho VB. Da guerra às emoções: história da internet e o controverso surgimento do Facebook. In: Encontro Regional Norte de História da Mídia no 4; 2016, mai 19-20. Rio Branco (AC); 2016.

29. Carvalho Júnior CF, Arrais CMC, Carvalho KSA, Ribeiro AJM. A evolução da internet: uma visão geral. In: Jornada de Iniciação Científica e Extensão no 8; 2017, out 25-27. Gurupi (TO); 2017.

30. Zanferrari MP, Corrêa CC, Wen CL, Félix GB. Development and application of an administrative instrument to guide research on telehealth in speech and language pathology. Rev. CEFAC. 2016;18(2):459-69.

31. Martins A, Franco EC, Caldana ML. Developing and evaluation of a website about children's language development: Portal dos Bebês - desenvolvimento da linguagem. Rev. CEFAC. 2015;17(1):159-68.

32. Carvalho RP, Munhoz GS, Lopes AC. Elaboração de um website sobre saúde auditiva para Músicos. Rev. Portuguesa de Saúde Ocupacional. 2016;1(1):61-71.

33. Martinelli VLC, Martinelli RLC, Marchesan IQ, Queiroz I, Berretin-Felix G, Souza SRS. Design and development of the "Neonatal Tongue Screening Test” website. Rev. CEFAC. 2017;19(2):260-4. 